\title{
EXTRACTANTS TO ASSESS ZINC PHYTOAVAILABILITY IN MINERAL FERTILIZER AND INDUSTRIAL BY-PRODUCTS ${ }^{(1)}$
}

\author{
Camila Prado Cenciani de Souza ${ }^{(2)}$, Cleide Aparecida de Abreu ${ }^{(3)}$, Cristiano Alberto de \\ Andrade $^{(4)}$ \& Mônica Ferreira de Abreu ${ }^{(3)}$
}

\begin{abstract}
SUMMARY
Efficient analytical methods for the quantification of plant-available $\mathrm{Zn}$ contained in mineral fertilizers and industrial by-products are fundamental for the control and marketing of these inputs. In this sense, there are some doubts on the part of the scientific community as well as of the fertilizer production sector, whether the extractor requested by the government (Normative Instruction No. 28 , called $2^{\text {nd }}$ extractor), which is citric acid $2 \%(2 \% \mathrm{CA})($ Brasil, 2007b), is effective in predicting the plant availability of $\mathrm{Zn}$ via mineral fertilizers and about the agronomic significance of the required minimal solubility of $60 \%$ compared to the total content ( $\mathrm{HCl}$ (Brasil, 2007a). The purpose of this study was to evaluate the alternative extractors DTPA, EDTA, neutral ammonium citrate (NAC), buffer solution pH 6.0, $10 \% \mathrm{HCl}, 10 \%$ sulfuric acid, $1 \%$ acetic acid, water, and hot water to quantify the contents of $\mathrm{Zn}$ available for maize and compare them with indices of agronomic efficiency of fertilizers and industrial by-products when applied to dystrophic Clayey Red Latosol and Dystrophic Alic Red Yellow Latosol with medium texture. The rate of $\mathrm{Zn}$ applied to the soil was $5 \mathrm{mg} \mathrm{kg}^{-1}$, using the sources zinc sulfate, commercial granular zinc, ash and galvanic sludge, ash and two brass slags. Most Zn was extracted from the sources by DTPA, $10 \% \mathrm{HCl}$, NAC, $1 \%$ acetic acid, and $10 \%$ sulfuric acid. Recovery by the extractors $2 \%$ CA, EDTA, water, and hot water was low. The agronomic efficiency index was found to be high when using galvanic sludge $(238 \%)$ and commercial granular zinc $(142 \%)$ and lower with brass slag I and II (67 and $27 \%$, respectively). The sources galvanizing ash and brass ash showed solubility lower than $60 \%$ in $2 \% \mathrm{CA}$, despite agronomic efficiency indices of 78 and $125 \%$, respectively. The low agronomic efficiency index of
\end{abstract}

\footnotetext{
(1) Part of the dissertation of the first author submitted to the Agronomic Institute of Campinas (IAC). Project (FAPESP 2009/01946-0) and the postgraduate scholarship (FAPESP 2010/04076-3) funded by State of São Paulo Research Foundation (FAPESP). Received for publication on August 9, 2012 and approved on April 17, 2013.

(2) Ph.D student in Agri-Environmental Resource Management at Center of Soil and Environmental Resources in IAC. Barão de Itapura Avenue, 1481. PO Box. 28. CEP 13012-970 Campinas (SP), Brazil. E-mail: ccencian@yahoo.com.br

(3) Researcher, Center of Soil and Environmental Resources in IAC. E-mail: cleide@iac.sp.gov.br; monica@iac.sp.gov.br

(4) Researcher of Embrapa Environment. Rodovia SP 340, Km 127,5. PO Box 69. CEP 13820-000 Jaguariúna (SP), Brazil. E-mail: cristiano.andrade@embrapa.br
} 


\begin{abstract}
industrial by-products such as brass slag I and galvanizing ash can be compensated by higher doses, provided there is no restriction, as well as for all other sources, in terms of contaminant levels of arsenic, cadmium, chromium, lead, and mercury as required by law (Normative Instruction No 27/2006). The implementation of $2^{\text {nd }}$ extractor $2 \% \mathrm{CA}$ and the requirement of minimum solubility for industrial byproducts could restrict the use of alternative sources as potential $\mathrm{Zn}$ sources for plants.
\end{abstract}

Index terms: maize, micronutrients, industrial waste, solubility, Zea mays.

\title{
RESUMO: EXTRATORES PARA AVALIAÇÃO DA FITODISPONIBILIDADE DE ZINCO EM FERTILIZANTES MINERAIS E MATERIAIS SECUNDÁRIOS
}

\begin{abstract}
A utilização de métodos analíticos eficientes na quantificação do Zn fitodisponível contido em fertilizantes minerais e materiais secundários é fundamental no controle e na comercialização desses insumos. Nesse sentido, há dúvidas no setor científico e no de produção de fertilizantes se o extrator exigido na Instrução Normativa $n^{\circ}$ 28, ácido cítrico $2 \%$ (AC $2 \%$ ) (Brasil, 2007b), chamado de $2^{\circ}$ extrator, é eficiente na predição da fitodisponibilidade de Zn em fertilizantes minerais e qual o significado agronômico da solubilidade mínima exigida de $60 \%$, em relação ao teor total (HCl) (Brasil, 2007a). O objetivo deste estudo foi avaliar os extratores alternativos DTPA, EDTA, CNA, solução-tampão pH 6,0, HCl $10 \%$, ácido sulfúrico $10 \%$, ácido acético $1 \%$, água e água quente na quantificação do teor disponível de $\mathrm{Zn}$ ao milho, confrontando com indices de eficiência agronômica de fertilizantes minerais e materiais secundários em Latossolo Vermelho distrófico textura argilosa e em Latossolo Vermelho-Amarelo distrófico álico textura média. A dose de Zn aplicada aos solos foi de $5 \mathrm{mg} \mathrm{kg}^{-1}$ e utilizaram-se as fontes sulfato de $\mathrm{Zn}, \mathrm{Zn}$ granulado comercial, cinza e lama de galvanização e cinza e duas escórias de latão. A maior extração de Zn das fontes ocorreu por meio do uso dos extratores DTPA, HCl 10\%, CNA, ácido acético $1 \%$ e ácido sulfúrico $10 \%$. Houve baixa recuperação nos extratores AC $2 \%$, EDTA, água e água quente. Elevados índices de eficiência agronômica foram encontrados com o uso da lama de galvanização (238 \%) e do Zn granulado comercial (142\%) e os menores, com o uso das escórias de latão I II, com 67 e $27 \%$, respectivamente. As fontes cinza de galvanização e cinza de latão apresentaram solubilidade menor que $60 \%$ no AC $2 \%$; no entanto, com índices de eficiência agronômica de 78 e $125 \%$, respectivamente. A baixa eficiência agronômica de materiais secundários como escória de latão I e cinza de galvanização pode ser compensada pelo aumento da dose, desde que não haja restrição, assim como para todas as demais fontes, quanto aos teores dos contaminantes arsênio, cádmio, cromo, chumbo e mercúrio, conforme exigido na legislação brasileira (Instrução Normativa $n^{\circ}$ 27 /2006). O extrator DTPA $50 \mathrm{mmol} \mathrm{L}^{-1}$, sob agitação, foi o que melhor representou a disponibilidade de Zn no milho em ambos os solos. A implementação do $2^{o}$ extractor AC $2 \%$ e a exigência da solubilidade mínima para materiais secundários poderia restringir o uso de fontes alternativas e com potencial para fornecimento de Zn às plantas.
\end{abstract}

Termos de indexação: adubos minerais, micronutrientes, resíduos industriais, solubilidade, Zea mays.

\section{INTRODUCTION}

After technological innovation in agriculture has boosted crop yields, any further advance will depend increasingly on improving the factors of production efficiency. One example is the application of micronutrients to the soil, becoming increasingly relevant in the agricultural sector of Brazil. A 13-fold increase was reported for the consumption of such inputs from 1990 to 2003 , whereas grain yield increased by $112 \%$ in this period (Yamada, 2004).

Among the micronutrients, zinc $(\mathrm{Zn})$ is particularly noteworthy. In $20 \%$ of 7,816 soil samples of the State of São Paulo and in $33 \%$ of 5,614 soil samples from other States, extracted by DTPA at pH 7.3 (Abreu et al., 2005), the Zn content was considered low ( $<0.5 \mathrm{mg} \mathrm{dm}^{-3}$ ) (Raij et al., 2001). The application of $\mathrm{Zn}$-containing fertilizers is therefore becoming increasingly important for a number of different crops.

Specifications, contents and other aspects related to the use of fertilizers containing micronutrients are defined by the Ministry of Agriculture, Livestock and Supply (MAPA) in the Normative Instruction No 05 (NI 05) (Brasil, 2007a) and the methods of nutrient quantification in Normative Instruction No 28 (Brasil, 
$2007 \mathrm{~b})$. One of the conditions of these regulations for soil application of mineral fertilizers is the determination of the total content of micronutrients in $\mathrm{HCl}$ (Brasil, 2007b) and of the soluble content, determined by a second extractor. For $\mathrm{Zn}$, this should be less than $60 \%$ in $2 \%$ citric acid solution $\left(2^{\text {nd }}\right.$ extractor), expressed in relation to the total content (Brasil, 2007a). Although these requirements ensure the quality of the raw material used for fertilizers, there are doubts as to whether the adopted extractant is efficient in determining the phytoavailability of $\mathrm{Zn}$ for the whole range of raw materials and fertilizers on the market. Secondly, there are doubts in agronomic terms, whether the required minimum solubility of $60 \%$ in the $2^{\text {nd }}$ extractor is adequate, since a lower solubility can be compensated by a higher application rate in the field.

Options of raw material for the production of Zncontaining fertilizers are scarce and some industrial by-products called secondary material could be an alternative to increase the range of these options, but must also meet the legal requirements of NI 05 (Brasil, 2007a). In this regard, studies to evaluate the solubility in the $2^{\text {nd }}$ extractor like used for commercial fertilizers are important. However, it is possible that an agronomically efficient $\mathrm{Zn}$-supplier is banned as raw material from fertilizer production, for simply not meeting the solubility requirements in the $2^{\text {nd }}$ extractor, with questionable validity, as mentioned.

The use of industrial by-products as input in the production of mineral fertilizers for soil application, as established in NI 05 (Brasil, 2007a), is allowed, provided that the state environmental agency approves its as well the MAPA the use of the residual material like zinc source for the production of fertilizer in the state where this industrial by-product is generated. In addition to the total content, the industrial by-products available on the market as raw material must be evaluated for solubility, agronomic efficiency and contaminant levels (of As, $\mathrm{Cd}, \mathrm{Cr}, \mathrm{Pb}$, and $\mathrm{Hg}$ ).

The objective of this study was to evaluate alternative extractors to $2 \%$ citric acid, to quantify the soluble $\mathrm{Zn}$ content in industrial by-products and mineral fertilizers for soil application, and compare the agronomic efficiency of these $\mathrm{Zn}$ sources in a greenhouse experiment with maize plants.

\section{MATERIAL AND METHODS}

The study was divided into two phases: phase I consisted of a qualitative characterization of the main minerals present in the samples by X-ray diffraction, performed at the Institute of Biological Sciences and the Federal University of Ouro Preto/MG, and the quantification of the $\mathrm{Zn}$ levels soluble in the $2^{\text {nd }}$ extractor and of the total content in $\mathrm{HCl}$; both analyses were performed at the soil science center of the Agronomic Institute of Campinas (IAC), in Campinas, São Paulo.

Phase II was conducted in a greenhouse at the IAC soil science center, where maize plants were grown in pots to assess the plant availability of Zn as well as the agronomic efficiency of sources. The goal was to approve and discard source materials in a selection based on the required minimum level (60\% in $2 \%$ $\mathrm{CA}$ compared to the total content in $\mathrm{HCl}$ ). Maize was chosen for being highly responsive to $\mathrm{Zn}$ application (Malavolta, 1996; Gupta, 2001).

\section{Phase I: Mineralogical characterization and levels of soluble $\mathrm{Zn}$ in $2^{\text {nd }}$ extractors}

For the evaluation of the minerals present in the samples and quantification of soluble levels in $2^{\text {nd }}$ extractors, the samples (Table 1) were divided into four, ground and sieved (standardized ABNT 20, mesh $0.84 \mathrm{~mm}$ (Brasil, 2007b).

In the X-ray diffraction analysis, a sample from each source was used and the X-ray diffractograms were obtained using a Shimadzu XRD-6000 diffractometer, equipped with an iron tube and graphite monochromator. Measurements were programmed at a speed of $2 \%$ min between $5-70{ }^{\circ}(2 \theta)$. The X-ray diffractograms were interpreted using Jade software.

To determine the total contents and levels of soluble $\mathrm{Zn}$ in the $2^{\text {nd }}$ extractant solution, three samples plus a blank control were used in all extractions. The analytical quantification was performed using the technique of inductively coupled plasma with optical emission spectrometry (ICPOES).

The following $2^{\text {nd }}$ extractants were evaluated for solubility of $\mathrm{Zn}$ sources: $2 \%$ citric acid, neutral ammonium citrate+water $1: 1,10 \% \mathrm{H}_{2} \mathrm{SO}_{4}, 10 \% \mathrm{HCl}$, $1 \%$ acetic acid, ethylenediaminetetraacetic acid (EDTA) $5 \mathrm{mmol} \mathrm{L}^{-1}$, diethylenetriaminepentaacetic acid (DTPA) $50 \mathrm{mmol} \mathrm{L}^{-1}$, buffer solution $0.24 \mathrm{~mol} \mathrm{~L}^{-1}$ Bis (hydroxymethyl)-2,2',2"-nitrilotriethanol $\left(\mathrm{C}_{8} \mathrm{H}_{19} \mathrm{NO}_{5}\right) \mathrm{pH} 6.0$, hot water, and water.

\section{Total zinc content}

We used the official MAPA method with concentrated $37 \% \mathrm{HCl}$ (Brasil, 2007b). A $150 \mathrm{~mL}$ beaker with $1.0000 \mathrm{~g}$ sample and $10 \mathrm{~mL} \mathrm{HCl}$ was covered with watch glass, heated on a hot plate $\left(160^{\circ}\right)$ and evaporated to near dryness. The residue was then dissolved in $20 \mathrm{~mL} \mathrm{HCl} 1+5$ and simmered on the hot plate. The extracts were removed from the plate and, after cooling, filtered through Whatman filter paper (No. 42), and the volume completed to $100 \mathrm{~mL}$ with deionized water.

\section{Soluble $\mathrm{Zn}$ content in $2 \%$ citric acid ( $2 \% \mathrm{CA})$}

Zinc was extracted according to the official method of MAPA (Brasil, 2007b). Beginning with a $1.0000 \mathrm{~g}$ 
Table 1. Zn sources evaluated for mineralogical composition and soluble contents in $2^{\text {nd }}$ extractors

\begin{tabular}{|c|c|c|c|}
\hline Zn source & Total $\mathrm{Zn}$ content & Type & Form \\
\hline & $\%$ (mass/mass basis) & & \\
\hline Galvanizing ash & 71 & $\mathrm{IB}^{(1)}$ & powder \\
\hline Galvanic sludge & 21 & IB & powder \\
\hline Brass ash & 72 & IB & powder \\
\hline Brass slag I & 19 & IB & powder \\
\hline Brass slag II & 15 & IB & powder \\
\hline Commercial granulated Zn Gran. & 27 & $\mathrm{~F}^{(2)}$ & granulated $^{(4)}$ \\
\hline Zn sulfate ${ }^{(5)}$ & 36 & F-RM ${ }^{(3)}$ & powder \\
\hline
\end{tabular}

${ }^{(1)}$ IB: industrial by-products with potential for use as raw material in fertilizer production. ${ }^{(2)} \mathrm{F}$ : fertilizer registered and available on the market. ${ }^{(3)}$ F-RM: material which can be marketed as raw material and as fertilizer. ${ }^{(4)}$ Fertilizer granulated with sulfuric acid at processing. ${ }^{(5)}$ Sample dried in a desiccator.

sample in a $150 \mathrm{~mL}$ beaker, $100 \mathrm{~mL}$ of $2 \%$ CA was added, placed on a hot plate and boiled for $10 \mathrm{~min}$. Then the extract was transferred to a $200 \mathrm{~mL}$ flask, the volume completed with deionized water, and filtered through Whatman filter paper (No. 42).

\section{Soluble Zn content in neutral ammonium citrate+water $(1: 1)$ (NAC)}

Zinc was extracted according to the official MAPA method used for $\mathrm{Cu}$ quantification by the $2^{\text {nd }}$ extractor, by the same extraction procedure as with $2 \% \mathrm{CA}$, but using neutral ammonium citrate+water (1:1) as extraction solution (Brasil, 2007b).

\section{Soluble Zn content in $10 \%(\mathrm{v} / \mathrm{v}) \mathrm{H}_{2} \mathrm{SO}_{4}$}

Zinc was extracted in $10 \% \mathrm{H}_{2} \mathrm{SO}_{4}$, as described by Bastos et al. (2007), by adding $0.5000 \mathrm{~g}$ of fertilizer to $30 \mathrm{~mL}$ of $10 \% \mathrm{H}_{2} \mathrm{SO}_{4}$ in a $250 \mathrm{~mL}$ Erlenmeyer flask. The mixture was boiled for $45 \mathrm{~min}$ on a hot plate and after cooling, the extract was filtered through Whatman filter paper (No. 42) and completed to $500 \mathrm{~mL}$.

\section{Soluble Zn content in $10 \%$ (v/v) HCl}

The procedure of $\mathrm{Zn}$ extraction from the samples was the same as described for extraction with $10 \%$ $\mathrm{H}_{2} \mathrm{SO}_{4}$ by Bastos et al. (2007). However, the $10 \%$ $\mathrm{H}_{2} \mathrm{SO}_{4}$ solution was replaced by $10 \% \mathrm{HCl}$ and heated under stirring. The set of a $0.5000 \mathrm{~g}$ sample $+30 \mathrm{~mL}$ of $10 \% \mathrm{HCl}$ was shaken for $1 \mathrm{~h}\left(3.14-4.19 \mathrm{rad} \mathrm{s}^{-1}\right)$ on a horizontal shaker (Marconi®, model MA 376), filtered through Whatman filter paper (No. 42) and completed to $250 \mathrm{~mL}$.

\section{Soluble $\mathrm{Zn}$ content in $1 \% \operatorname{acetic} \operatorname{acid}(\mathrm{v} / \mathrm{v})$ (1\% AA)}

Zinc was extracted from the sources by $1 \%$ acetic acid extractant, as described by Gallo (1954). A total of $1.2500 \mathrm{~g}$ sample was filled in $500 \mathrm{~mL}$ glass bottles containing $250 \mathrm{~mL} 1 \%$ acetic acid. The mixture was stirred for $30 \mathrm{~min}$ (3.14-4.19 $\left.\mathrm{rad} \mathrm{s}^{-1}\right)$ using a Wagner shaker (Tecnal®, TE-160). Subsequently, the extract was filtered through Whatman filter paper (No. 42).

\section{Soluble $\mathrm{Zn}$ content in $5 \mathrm{mmol} \mathrm{L}^{-1}$ EDTA}

The zinc was extracted from the samples as proposed by Vale \& Alcarde (1999). A total of $1.000 \mathrm{~g}$ of the sample was weighed in a $250 \mathrm{~mL}$ Erlenmeyer flask to which $100 \mathrm{~mL}$ of $5 \mathrm{mmol} \mathrm{L}^{-1}$ EDTA solution was added. In a Wagner shaker (Tecnal ${ }^{\circledR}$, model 315 ), the mixture was shaken for $1 \mathrm{~h}$ (3.14-4.19 $\left.\mathrm{rad} \mathrm{s}^{-1}\right)$. The extract was then filtered through Whatman filter paper (No. 42) and completed to $250 \mathrm{~mL}$.

\section{Soluble Zn content in $50 \mathrm{mmol} \mathrm{L}^{-1}$ DTPA}

Zinc was extracted from the sources by the method of Vale \& Alcarde (1999), changing the concentration of the DTPA extraction solution from 5 to $50 \mathrm{mmol} \mathrm{L}^{-1}$, due to the high $\mathrm{Zn}$ content in the samples. This DTPA concentration was obtained by stoichiometric calculation considering the possibility that DTPA could chelate all $\mathrm{Zn}$ present in the sample of $\mathrm{Zn}$ sulfate, based on the content of $35 \%$ stated by the manufacturer. A sample of $1.500 \mathrm{~g}$ was weighed and placed in a $250 \mathrm{~mL}$ Erlenmeyer flask with $100 \mathrm{~mL}$ of $50 \mathrm{mmol} \mathrm{L}-1$ DTPA. The mixture was shaken in a Wagner shaker (Tecnal $\AA$, model 315 ) for $1 \mathrm{~h} \mathrm{(3.14-}$ $4.19 \mathrm{rad} \mathrm{s}^{-1}$ ). After this period, the extract was filtered through Whatman filter paper (No. 42) and completed to $250 \mathrm{~mL}$.

\section{Soluble $\mathrm{Zn}$ content in $\mathrm{pH} 6.0$ buffer solution (pH BS 6.0)}

Zinc was extracted from the samples as described by FDACS (2008) by buffer solution $0.24 \mathrm{~mol} \mathrm{~L}^{-1} 2,2$ bis(hydroxymethyl)-2,22,23-nitrilotriethanol $\left(\mathrm{C}_{8} \mathrm{H}_{19} \mathrm{NO}_{5}\right) \mathrm{pH}$ 6.0. The procedure considered pure material which recommends $0.3-0.5 \mathrm{~g}$ fertilizer for $500 \mathrm{~mL}$ of extraction solution in a $1000 \mathrm{~mL}$ volumetric flask. Due to the high cost of chemicals, it was decided to reduce the amount of fertilizer and volume of the extraction solution, but at the same proportion. We used $125 \mathrm{~mL}$ of buffer solution $0.24 \mathrm{~mol} \mathrm{~L}^{-1} 2,2$ - 
bis(hydroxymethyl)-2,22,23-nitrilotriethanol $\left(\mathrm{C}_{8} \mathrm{H}_{19} \mathrm{NO}_{5}\right) \mathrm{pH} 6.0$ in a mixture of $0.1250 \mathrm{~g}$ of fertilizer in a $250 \mathrm{~mL}$ volumetric flask, completing the volume with deionized water and shaking vigorously by hand for $30 \mathrm{~s}$. The extract was left to stand overnight and the supernatant was analyzed.

\section{Soluble Zn content in hot water}

Zinc was extracted from the samples by the procedure of AOAC (1997) for analysis of soluble boron. A total of $2.0000 \mathrm{~g}$ sample was transferred to a 250 $\mathrm{mL}$ volumetric flask, plus $100 \mathrm{~mL}$ of deionized water, boiled for $30 \mathrm{~min}$ on a hot plate and then cooled to room temperature. The volume was completed to 250 $\mathrm{mL}$ and then vigorously shaken by hand for $30 \mathrm{~s}$ and filtered through Whatman filter paper (No. 42).

\section{Soluble Zn content in water}

Zinc was extracted from the sources with water as described by Vale \& Alcarde (1999). A funnel on a $250 \mathrm{~mL}$ volumetric flask was lined with Whatman filter paper (No. 42), on which $2.5000 \mathrm{~g}$ fertilizer sample was placed. The sample was washed successively with portions of deionized water, taking care to complete the suspension of the sample to $250 \mathrm{~mL}$.

The $\mathrm{Zn}$ content quantified in the $2^{\text {nd }}$ extractant solutions from the sources was subjected to analysis of variance (ANOVA) and means were compared using the Scott-Knott test at $95 \%$ probability. The extractors were considered as variation factors (10).

\section{Phase II: Zinc availability to maize plants}

The soils used in the greenhouse experiment were taken from the surface layer $(0-20 \mathrm{~cm})$ of a Dystrophic Clayey Red Latosol (DCRL) and a Dystrophic Alic Red Yellow Latosol (DARYL) with medium texture. The soils were acidic and the $\mathrm{Zn}$ contents in DTPA pH 7.3 were considered medium (Raij et al., 2001) (Table 2).

The soil samples were air-dried, sieved $(2 \mathrm{~mm})$ and limed to increase base saturation to $70 \%$ by the application of calcium carbonate + magnesium carbonate, both pure for analysis (PA), at a Ca: $\mathrm{Mg}$ ratio of $3: 1$. The pots were incubated for 20 days, maintaining moisture at around $60 \%$ of the total pore volume (TPV).

The experiment was arranged in a completely randomized factorial design: two soils $\mathrm{x}$ eight treatments (seven Zn sources + control) x four replications, for a total of 64 experimental units. The control treatments of each soil consisted of a sample without $\mathrm{Zn}$ application. The $\mathrm{Zn}$ sources used (Table 1) were applied in powder form at rates of $5 \mathrm{mg} \mathrm{kg}^{-1} \mathrm{Zn}$ (based on the total content), mixed with soil and other fertilizers for base fertilization and then incubated (moisture $60 \%$ TPV) for three days until maize sowing.

The fertilization at sowing consisted of $\mathrm{P}$ application (232 $\mathrm{mg} \mathrm{kg}^{-1}$ ) and a solution containing (in $\mathrm{mg} \mathrm{kg}^{-1}$ ):
$38 \mathrm{~N}, 190 \mathrm{~K}, 203 \mathrm{Ca}, 43 \mathrm{~S}, 0.5 \mathrm{~B}$ and $1.5 \mathrm{Cu}$; the DARYL soil also received $3 \mathrm{mg} \mathrm{kg}^{-1} \mathrm{Mn}$. The sources $\mathrm{KNO}_{3}, \mathrm{~K}_{2} \mathrm{HPO}_{4}, \mathrm{CaHPO}_{4}, \mathrm{H}_{3} \mathrm{BO}_{3}, \mathrm{CuSO}_{4}$, and $\mathrm{MnSO}_{4} \cdot \mathrm{H}_{2} \mathrm{O}$ were used in powder form and all sources were PA.

Ten seeds of hybrid maize, IAC 8333, treated with the fungicides Carboxin and Thiram, were sown in pots with $3 \mathrm{~kg}$ of soil and thinned to five vigorous and healthy maize plants per pot after one week. Soil moisture was maintained at around $80 \%$ of the TPV by addition of distilled water, defined by periodic weighing of the pots. During the test, $\mathrm{N}$ was sidedressed in the form of $\mathrm{Ca}\left(\mathrm{NO}_{3}\right)_{2} \cdot 4 \mathrm{H}_{2} \mathrm{O}$, in six applications of $50 \mathrm{mg} \mathrm{kg}^{-1}$ (equivalent to a total of 300 $\mathrm{mg} \mathrm{kg}^{-1} \mathrm{~N}$ and $430 \mathrm{mg} \mathrm{kg}^{-1} \mathrm{Ca}$ ), applied 4, 11, 18, 25, 32 , and 39 days after emergence (DAE).

The maize shoots were cut $48 \mathrm{DAE}$, washed in distilled water, dried at $65^{\circ} \mathrm{C}$ to constant weight, dry-

Table 2. Soils chemical and physical properties after liming in experiment with $\mathrm{Zn}$ sources to maize

\begin{tabular}{|c|c|c|}
\hline Determination & DCRL $^{(1)}$ & DARYL $^{(2)}$ \\
\hline $\mathrm{pH}^{(3)}$ & 5.3 & 5.3 \\
\hline $\mathrm{MO}^{(4)}, \mathrm{g} \mathrm{dm}^{-3}$ & 49 & 34 \\
\hline $\mathrm{P}^{(5)}, \mathrm{mg} \mathrm{dm}^{-3}$ & 7 & 6 \\
\hline $\mathrm{K}^{+(5)}, \mathrm{mmol}_{\mathrm{c}} \mathrm{dm}^{-3}$ & 1.2 & 1.4 \\
\hline $\mathrm{Ca}^{2+(5)}, \mathrm{mmol}_{\mathrm{c}} \mathrm{dm}^{-3)}$ & 44 & 28 \\
\hline $\mathrm{Mg}^{2+(5)}, \mathrm{mmol}_{\mathrm{c}} \mathrm{dm}^{-3}$ & 17 & 10 \\
\hline $\mathrm{Al}^{3+(6)}, \mathrm{mmol}_{\mathrm{c}} \mathrm{dm}^{-3}$ & 0 & 0 \\
\hline $\mathrm{H}+\mathrm{Al}^{(7)}, \mathrm{mmol}_{\mathrm{c}} \mathrm{dm}^{-3}$ & 38 & 31 \\
\hline $\mathrm{SB}, \mathrm{mmol}_{\mathrm{c}} \mathrm{dm}^{-3}$ & 62.3 & 40.0 \\
\hline CTC, $\mathrm{mmol}_{\mathrm{c}} \mathrm{dm}^{-3}$ & 100.3 & 70.8 \\
\hline $\mathrm{V},(\%)$ & 62 & 56 \\
\hline $\mathrm{S}^{(8)}, \mathrm{mg} \mathrm{dm}^{-3}$ & 10 & 16 \\
\hline $\mathrm{B}^{(9)}, \mathrm{mg} \mathrm{dm}^{-3}$ & 0.44 & 0.27 \\
\hline $\mathrm{Cu}^{2+(10)}, \mathrm{mg} \mathrm{dm}^{-3}$ & 0.4 & 2.7 \\
\hline $\mathrm{Fe}^{2+(10)}, \mathrm{mg} \mathrm{dm}^{-3}$ & 48 & 49 \\
\hline $\mathrm{Mn}^{2+(10)}, \mathrm{mg} \mathrm{dm}^{-3}$ & 4.3 & 1.8 \\
\hline $\mathrm{Zn}^{2+(10)}, \mathrm{mg} \mathrm{dm}^{-3}$ & 1 & 0.9 \\
\hline $\mathrm{Cd}^{2+(10)}, \mathrm{mg} \mathrm{dm}^{-3}$ & $<0.01$ & $<0.01$ \\
\hline $\mathrm{Cr}^{2+(10)}, \mathrm{mg} \mathrm{dm}^{-3}$ & $<0.01$ & $<0.01$ \\
\hline $\mathrm{Ni}^{2+(10)}, \mathrm{mg} \mathrm{dm}^{-3}$ & 0.03 & 0.07 \\
\hline $\mathrm{Pb}^{2+(10)}, \mathrm{mg} \mathrm{dm}^{-3}$ & 1.20 & 1.76 \\
\hline Clay ${ }^{(11)}, \mathrm{g} \mathrm{kg}^{-1}$ & 390 & 324 \\
\hline Silt $^{(11)}, \mathrm{g} \mathrm{kg}^{-1}$ & 196 & 86 \\
\hline $\operatorname{Sand}^{(11)}, \mathrm{g} \mathrm{kg}^{-1}$ & 414 & 590 \\
\hline
\end{tabular}

(1) DCRL: Dystrophic Clayey Red Latosol; ${ }^{(2)}$ DARYL: Dystrophic Alic Red Yellow Latosol medium texture; ${ }^{(3)}$ Determination in $\mathrm{CaCl}_{2}$; ${ }^{(4)}$ Colorimetric method-sulfuric acid and potassium dichromate; ${ }^{(5)}$ Ion exchange resin extractor; ${ }^{(6)} \mathrm{KCl}$ extractor; (7) SMP buffer solution; ${ }^{(8)}$ Calcium phosphate extractor; ${ }^{(9)}$ Hot water extractor; ${ }^{(10)}$ DTPA extractor $\mathrm{pH} 7.3$ and ICP-OES reading; ${ }^{(11)}$ Particle size: pipette method. The chemical analyses were performed according to Raij et al. (2001) and particle-size analyses as described by Camargo et al. (2009). 
weighed, and ground in a Willey mill. Roots and soil were separated by sieving, washed in tap water and soaked for $90 \mathrm{~min}$ in a $0.02 \mathrm{mmol} \mathrm{L}^{-1}$ disodium EDTA solution (Gabos, 2008). Then the roots were washed thoroughly in distilled water, dried and ground as done with the shoots. The levels of macronutrients and micronutrients were determined by microwave digestion with concentrated $\mathrm{HNO}_{3}$ and $\mathrm{H}_{2} \mathrm{O}_{2}$ (Abreu et al., 1997) and ICP-OES readings.

The $\mathrm{Zn}$ recovered from the sources by maize plants was calculated using the agronomic efficiency index (AEI) of the sources in relation to zinc sulfate:

$$
\operatorname{AEI}(\%)=\frac{A_{\text {source }}-A_{\text {control }}}{A_{\text {standsource }}-A_{\text {control }}} \times 100
$$

where: $\mathrm{A}_{\text {source}}$ : $\mathrm{Zn}$ accumulation (mg/pot) in shoots of plants grown in pots containing industrial byproducts/fertilizers;

$\mathrm{A}_{\text {control: }}: \mathrm{Zn}$ accumulation (mg/pot) in shoots of plants grown in pots without addition of industrial byproducts/fertilizers; and

$\mathrm{A}_{\text {standard source: }} \mathrm{Zn}$ accumulation (mg/pot) in shoots of plants grown in pots containing zinc sulfate.

The Zn concentration in maize shoots associated with the respective dry mass were used to calculate $\mathrm{Zn}$ accumulation by the plant.

The statistical analysis was based on analysis of variance and subsequent comparison of means using the Scott-Knott test at $95 \%$ probability. The evaluation of the $2^{\text {nd }}$ extractors with the aim of identifying and discussing the most promising extractor(s) was based on statistical correlations between the calculated amount of potentially available $\mathrm{Zn}$ (mg/pot), considering the total $\mathrm{Zn}$ content and the soluble $\mathrm{Zn}$ in each extractor versus $\mathrm{Zn}$ accumulation $(\mathrm{mg} / \mathrm{pot})$ in maize plants.

\section{RESULTS AND DISCUSSION}

\section{Phase I: Mineralogical characterization and levels of soluble $\mathrm{Zn}$ in $2^{\text {nd }}$ extractors}

The galvanizing ash generated in the hot-dip galvanizing process contained zincite $(\mathrm{ZnO})$ and simonkolleite (Zinc chloride hydroxide monohydrate $\left.\mathrm{Zn}_{5}(\mathrm{OH})_{8} \mathrm{Cl}_{2} \cdot \mathrm{H}_{2} \mathrm{O}\right)$ as major $\mathrm{Zn}$ mineral forms (Table 3). The presence of quartz indicated the use of silicon as fluxing agent in the process.

In the galvanic sludge, an industrial by-product resulting from cold galvanizing, $\mathrm{Zn}$ was in oxide (Zincite - $\mathrm{ZnO})$ and in hydroxide form $\left(\mathrm{Zn}(\mathrm{OH})_{2}\right)$. The sample also contained quartz $\left(\mathrm{SiO}_{2}\right)$, calcium carbonate (calcite - $\mathrm{CaCO}_{3}$ ) and gypsum (calcium sulfate dihydrate - $\mathrm{CaSO}_{4} \cdot 2 \mathrm{H}_{2} \mathrm{O}$ ) (Table 3 ). The appearance of $\mathrm{Zn}$ hydroxide must be related to the higher $\mathrm{pH}$, due to the use of calcium carbonate with the function of precipitating metal ions in solution. Gypsum resulted from the use of zinc sulfate solution in the process (Gomide, 2009), where part of the sulfate is precipitated later with calcium.

In the brass ash sample, $\mathrm{Zn}$ is present in the oxide form (Zincite - $\mathrm{ZnO}$ ) (Table 3). The presence of three lead minerals was detected: matlockite $(\mathrm{Pb}$ fluorochloride - $\mathrm{PbClF})$, cerussite $(\mathrm{Pb}$ hydroxide carbonate $\left.-\mathrm{Pb}_{3}\left(\mathrm{CO}_{3}\right)_{2}(\mathrm{OH})_{2}\right)$ and of a $\mathrm{Pb}$ oxide chloride fluoride $\left(\mathrm{Pb}_{2} \mathrm{OFCl}\right)$ (Table 3). The lead in this industrial by-product of brass and bronze alloy production may have originated from the use of scrap in the process or from $\mathrm{Pb}$ addition for metallurgical purposes (Gomide, 2009). Since lead is a volatile element, its accumulation in this industrial by-product is facilitated, since it is captured at the system outlet (baghouse filters).

In the sample of brass slag I, Zn was predominantly found in the form of oxide (Zincite $\mathrm{ZnO}$ ) and bonded to oxygen and aluminum in the mineral gahnita $\left(\mathrm{ZnAl}_{2} \mathrm{O}_{4}\right)$ (Table 3 ). These $\mathrm{Zn}$ forms were expected since silicon was added in the generation process of this industrial by-product in the form of $\mathrm{SiO}_{2}$ (Gomide, 2009). The presence of aluminum oxide (corundum $-\mathrm{Al}_{2} \mathrm{O}_{3}$ ) (Table 3) indicates that this material may have been mixed with ash or slag from the production of Zamak alloys, which normally contain aluminum.

Brass slag II contained the minerals quartz $\left(\mathrm{SiO}_{2}\right)$ and $\mathrm{Zn}$ in the form of silicate in willemite $\left(\mathrm{Zn}_{2} \mathrm{SiO}_{4}\right)$ (Table 3), which is consistent with the use of silicon as a fluxing agent (Gomide, 2009).

In the composition of commercial granular $\mathrm{Zn}$ fertilizer, $\mathrm{Zn}$ was found in the form of oxide (zincite $\mathrm{ZnO}$ ), sulfate (gunningite - $\mathrm{ZnSO}_{4}\left(\mathrm{H}_{2} \mathrm{O}\right)$ and bianchite - $\mathrm{Zn}\left(\mathrm{SO}_{4}\right)\left(\mathrm{H}_{2} \mathrm{O}\right)_{6}$ (Table 3). The presence of $\mathrm{Zn}$ sulfate must be a result of the reaction with sulfuric acid in the granulation process. The aluminum oxide (corundum $-\mathrm{Al}_{2} \mathrm{O}_{3}$ ) (Table 3) found in the commercial product indicates the inclusion of industrial byproducts available on the agricultural market as raw material in the production of this fertilizer. This occurs due to the limited availability of raw material regulated by MAPA as well as its high cost compared to alternative sources.

The synthetic mineral gunningite was detected in the zinc sulfate sample, which is $\mathrm{Zn}$ in the form of sulfate $\left(\mathrm{ZnSO}_{4} \cdot \mathrm{H}_{2} \mathrm{O}\right)$ (Table 3$)$. For being a sample of an industrial process, it contained no other substances or contaminants.

The information about the mineralogical composition of industrial by-products and mineral fertilizers was useful in the interpretation of the results of solubility and agronomic efficiency, as shown below. Importantly, X-ray diffraction analysis is a promising tool in the description of this type of material and can even detect possible frauds in raw material and commercial products. 
Table 3. Mineralogical composition of zinc sources by X-ray diffraction

\begin{tabular}{|c|c|c|c|}
\hline Source & Mineral $^{(1)}$ & Chemical formula & PDF card no. \\
\hline \multirow[t]{3}{*}{ Galvanizing ash } & Zincite (Zn oxide) & $\mathrm{ZnO}$ & $01-070-2551$ \\
\hline & $\begin{array}{l}\text { Simonkolleite (Zn chloride } \\
\text { hydroxide monohydrate) }\end{array}$ & $\mathrm{Zn}_{5}(\mathrm{OH})_{8} \mathrm{Cl}_{2} \cdot \mathrm{H}_{2} \mathrm{O}$ & 01-077-2311 \\
\hline & Quartz & $\mathrm{SiO}_{2}$ & $00-085-2237$ \\
\hline \multirow[t]{5}{*}{ Galvanic sludge } & Gypsum (calcium sulfate dihydrate) & $\mathrm{CaSO}_{4} \cdot 2 \mathrm{H}_{2} \mathrm{O}$ & 00-033-0138 \\
\hline & Zn hydroxide & $\mathrm{Zn}(\mathrm{OH})_{2}$ & 01-089-0138 \\
\hline & Zincite (Zn oxide) & $\mathrm{ZnO}$ & $01-070-2551$ \\
\hline & Calcite (Ca carbonate) & $\mathrm{CaCO}_{3}$ & 01-086-0174 \\
\hline & Quartz & $\mathrm{SiO}_{2}$ & 01-085-2237 \\
\hline \multirow[t]{4}{*}{ Brass ash } & Zincite (Zn oxide) & $\mathrm{ZnO}$ & $01-070-2551$ \\
\hline & Matlockite (Pb fluorochloride) & $\mathrm{PbClF}$ & 00-026-0311 \\
\hline & Cerussite ( $\mathrm{Pb}$ hydroxide carbonate) & $\mathrm{Pb}_{3}\left(\mathrm{CO}_{3}\right)_{2}(\mathrm{OH})_{2}$ & 00-013-0131 \\
\hline & $\mathrm{Pb}$ oxide chloride fluoride & $\mathrm{Pb}_{2} \mathrm{OFCl}$ & 01-083-2117 \\
\hline \multirow[t]{6}{*}{ Brass slag I } & Corundum (Al oxide) & $\mathrm{Al}_{2} \mathrm{O}_{3}$ & 01-076-0144 \\
\hline & Zincite (Zn oxide) & $\mathrm{ZnO}$ & $01-070-2551$ \\
\hline & Gahnita ( $\mathrm{Zn}$ and $\mathrm{Al}$ oxide) & $\mathrm{ZnAl}_{2} \mathrm{O}_{4}$ & 01-082-1534 \\
\hline & Copper & $\mathrm{Cu}$ & 03-065-9026 \\
\hline & Tenorite $(\mathrm{Cu}$ oxide $)$ & $\mathrm{CuO}$ & 01-073-6023 \\
\hline & Si oxide & $\mathrm{SiO}_{2}$ & 01-089-8939 \\
\hline \multirow[t]{2}{*}{ Brass slag II } & Willemite & $\mathrm{Zn}_{2} \mathrm{SiO}_{4}$ & 01-070-1235 \\
\hline & Quartz & $\mathrm{SiO}_{2}$ & $01-085-2237$ \\
\hline \multirow[t]{4}{*}{ Commercial granular Zn } & Corundum (Al oxide) & $\mathrm{Al}_{2} \mathrm{O}_{3}$ & 01-076-0144 \\
\hline & Zincite (Zn oxide) & $\mathrm{ZnO}$ & $01-073-8765$ \\
\hline & Gunningite (hydrated Zn sulfate) & $\mathrm{ZnSO}_{4}\left(\mathrm{H}_{2} \mathrm{O}\right)$ & 01-074-1331 \\
\hline & Bianchite (hydrated Zn sulfate) & $\mathrm{Zn}\left(\mathrm{SO}_{4}\right)\left(\mathrm{H}_{2} \mathrm{O}\right)_{6}$ & 01-075-0949 \\
\hline Zn sulfate & Gunningite (hydrated Zn sulfate) & $\mathrm{ZnSO}_{4}\left(\mathrm{H}_{2} \mathrm{O}\right)$ & 01-074-1331 \\
\hline
\end{tabular}

(1) More details see Souza (2012).

\section{Levels of soluble $\mathrm{Zn}$ in $2^{\text {nd }}$ extractors}

Most Zn sources were approved, for reaching the required minimum solubility of $60 \%$ in the $2 \%$ CA extractor compared to the total content, with the exception of galvanizing ash and brass ash (Table 4). Both galvanizing ash and brass ash contained $\mathrm{Zn}$ in the oxide form (zincite) (Table 3), as similarly found in other sources that reached the minimum solubility threshold in the $2^{\text {nd }}$ extractor. The difference is that in these materials, Zn concentrations exceeded $70 \%$, which may have saturated the oxidative capacity of citric acid. Further studies are needed to evaluate the relationship mass of fertilizer: extraction solution, which is currently $1.0 \mathrm{~g}: 100 \mathrm{~mL}$, or higher citric acid concentrations to analyze very concentrated $\mathrm{Zn}$ sources, but in authorized soluble forms ( $\mathrm{Zn}$ oxide).

The $2^{\text {nd }}$ extractants tested alternately to $2 \%$ citric acid differed significantly in relation to the $\mathrm{Zn}$ content of mineral fertilizers and industrial by-products (Table 5). In general, the extraction capacity of DTPA and $10 \% \mathrm{HCl}$ was highest, followed by NAC, $1 \% \mathrm{AA}$ and $10 \%$ SA (Table 5).

The Zn levels extracted by the methods with the strong acids $\mathrm{HCl}$ and $\mathrm{AS}$, both diluted to $10 \%$, was higher than of those extracted by $2 \%$ CA (115 and $143 \%$, respectively) (Table 6). This fact can be explained by the higher solubility of the sources due the acidity of the medium. In the case of the solutions $10 \% \mathrm{HCl}$ and $10 \% \mathrm{SA}$, the $\mathrm{pH}$ values were zero, but 2.3 in the solution of $2 \% \mathrm{CA}$.

However, the effect of acidity of the medium was not the decisive factor in the $\mathrm{Zn}$ extraction by $2 \% \mathrm{CA}$ compared with NAC ( $\mathrm{pH}$ values of 2.3 and 7.0, respectively). The greater extraction capacity of NAC $(127 \%)$ (Table 6) can be attributed to the higher stability of the $\mathrm{Zn}$-citrate chelate formed at neutral $\mathrm{pH}$ than under acidic conditions, as in the case of the extractor $2 \% \mathrm{CA}$. The $\mathrm{pH}$ value of 2.3 hampers the deprotonation of the three molecules of carboxyl groups of CA, which is an indispensable condition for the release of oxygen as electron donor group to the metal in chelate (Alcarde \& Ponchio, 1979), resulting in a 
Table 4. Solubility level required by MAPA and observed for Zn sources using the official $2^{\text {nd }}$ extractor $2 \%$ citric acid ( $2 \% \mathrm{CA})$

\begin{tabular}{|c|c|c|c|c|c|}
\hline Source & Total content $\mathrm{HCl}$ & Requirement $2 \% \mathbf{C A}^{(1)}$ & Content $2 \% \mathbf{C A}^{(2)}$ & $\mathbf{Z n}$ in $2 \% \mathbf{C A}^{(3)}$ & Status ${ }^{(4)}$ \\
\hline & & $\% \mathrm{Zn}$ (mass/mass & basis) & & \\
\hline Galvanizing ash & $71 \pm 2.10$ & 43 & $31 \pm 1.78$ & 43 & $\mathrm{D}$ \\
\hline Galvanic sludge & $21 \pm 1.15$ & 13 & $25 \pm 0.20$ & 116 & $\mathrm{~A}$ \\
\hline Brass ash & $72 \pm 1.72$ & 43 & $35 \pm 4.45$ & 49 & $\mathrm{D}$ \\
\hline Brass slag I & $19 \pm 0.60$ & 11 & $18 \pm 0.45$ & 97 & A \\
\hline Brass slag II & $15 \pm 0.25$ & 9 & $12 \pm 0.15$ & 77 & A \\
\hline Commercial granular $\mathrm{Zn}$ & $27 \pm 1.43$ & 16 & $29 \pm 1.25$ & 107 & A \\
\hline Zn sulfate ${ }^{(5)}$ & $36 \pm 1.20$ & 21 & $42 \pm 1.25$ & 118 & $\mathrm{~A}$ \\
\hline
\end{tabular}

(1) It was considered that MAPA requirement solubility in the $2^{\text {nd }}$ extractor $2 \%$ citric acid (2\% CA) equivalent to $60 \%$ of the total content in $\mathrm{HCl}$ extractor was also required for industrial by-products. ${ }^{(2)}$ Soluble content in the $2^{\text {nd }}$ extractor $2 \%$ citric acid (2\% CA). (3) $\% \mathrm{Zn}$ (mass/mass basis) in $2 \%$ citric acid (2\% CA) compared to the total content as $100 \%$. ${ }^{(4)}$ Status A: approved and D: discarded, according to the minimum threshold of MAPA. ${ }^{(5)}$ Sample dried in a desiccator.

Table 5. Zn contents extracted by the $2^{\text {nd }}$ extractors in mineral fertilizers and industrial by-products

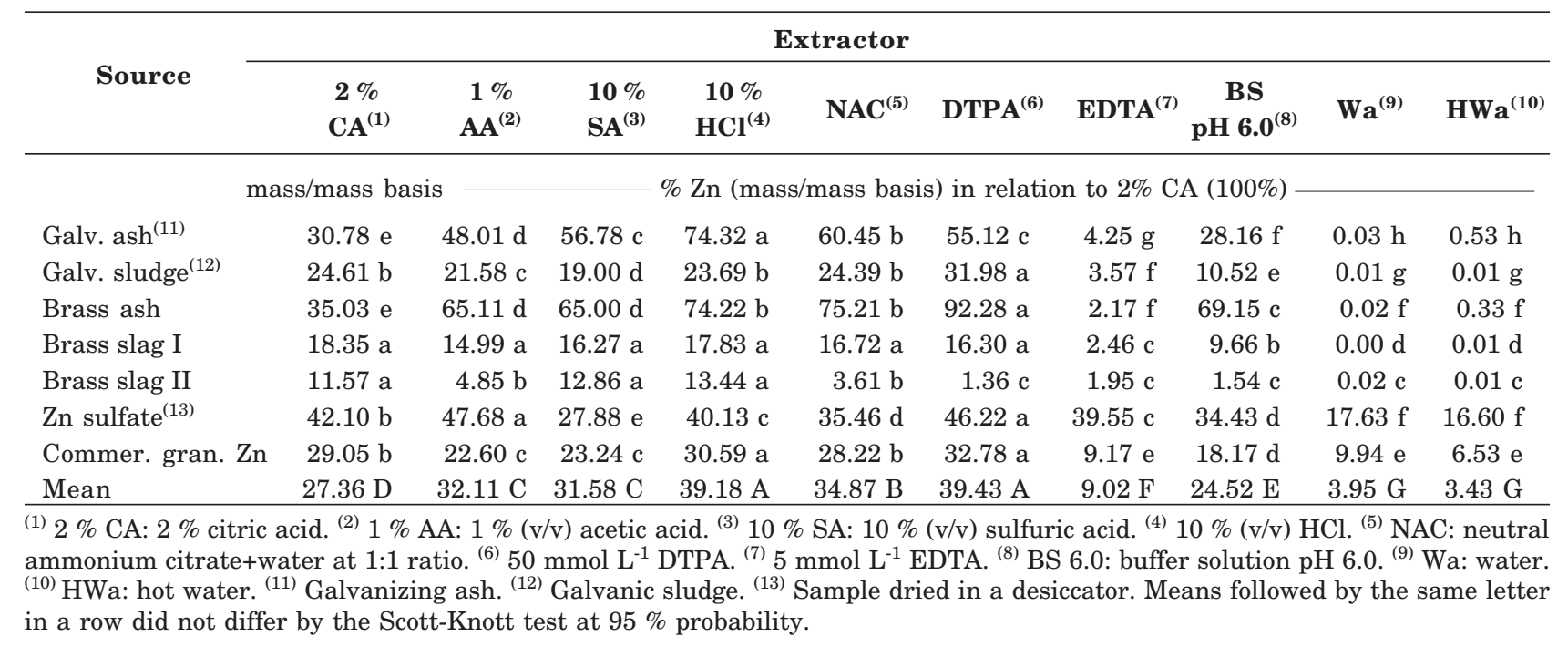

Table 6. Percentage of $\mathrm{Zn}$ recovered from the sources compared to the official MAPA extractor $2 \%$ citric acid (2\% CA)

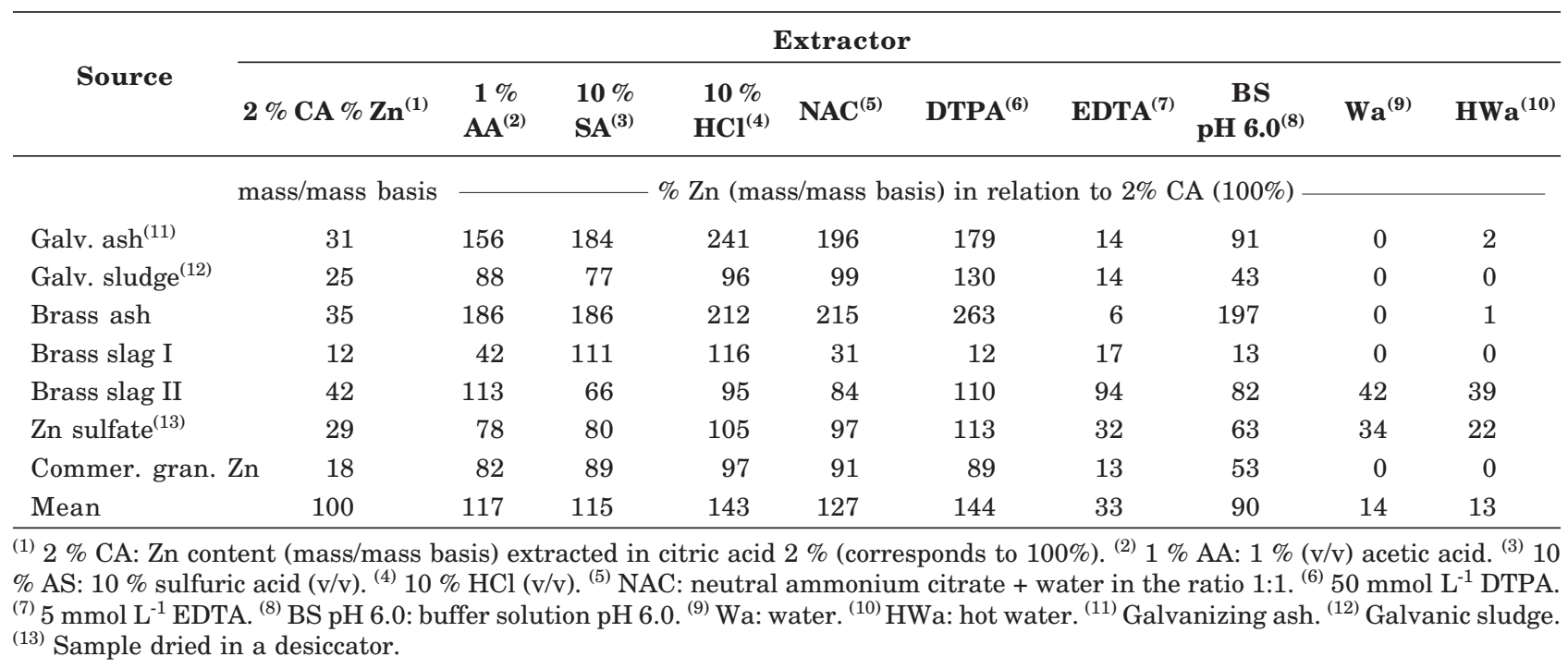


less intense complexing action in the solution of $2 \%$ CA than of NAC.

The percentage of $\mathrm{Zn}$ recovered by the extractors $2 \% \mathrm{CA}$ and $\mathrm{BS} \mathrm{pH} 6.0$ was moderate (Table 5 ). The extractor BS pH 6.0 extracted $90 \%$ of $2 \%$ CA (Table 6 ). The Zn extraction capacity of the extractors EDTA, Wa and HWa was low and the $\mathrm{Zn}$ percent recovery in relation to $2 \%$ CA was 33,14 and $13 \%$, respectively (Table 6). The low Zn contents extracted by the methods Wa and HWa were expected since almost all sources, except Zn sulfate, were water-insoluble.

In all studied materials, the $\mathrm{Zn}$ contents extracted by the chelating agent EDTA were very low and statistically lower than the DTPA-extracted levels (Tables 5 and 6). The stability constant of EDTA for metal micronutrients is higher than of DTPA so the opposite would be expected, namely, higher zinc extraction by EDTA. However, the concentration of DTPA solution $\left(50 \mathrm{mmol} \mathrm{L}^{-1}\right)$ was 10 times higher than EDTA, explaining the observed results. A study evaluating the solubility of some micronutrients, including $\mathrm{Zn}$, in 30 samples of commercial fertilizers extracted by DTPA and EDTA, both at $5 \mathrm{mmol} \mathrm{L}^{-1}$, as well as by the extractors water, $2 \% \mathrm{CA}$ and NAC diluted 1+9, showed low metal solubility in EDTA and DTPA. On this issue, the authors claimed that higher concentrations of these solutions of chelating extractants could be more effective in the evaluation of micronutrient solubility in fertilizers (Vale \& Alcarde, 1999). Another aspect is the high $\mathrm{Zn}$ concentration in the studied materials, exceeding the chelating capacity of the complexing agent, as reported by Norvell (1984) for high soil Cu concentrations, exceeding the chelating capacity of DTPA.

The $\mathrm{Zn}$ concentrations in galvanizing ash and brass ash, were lower than $60 \%$ solubility in the second extractor CA $2 \%$ (Table 4), but were high in the extractant solutions of $10 \% \mathrm{HCl}$ and NAC, and in DTPA for brass ash (Table 5). The $\mathrm{Zn}$ recovery rate from this ash by these extractants, expressed in relation to $2 \% \mathrm{CA}$, ranged from 96 to $241 \%$ (Table 6). Alcarde \& Rodella (1993) reported the highest Zn extraction capacity in $\mathrm{Zn}$ oxide, $\mathrm{PA}$, and the lowest in $\mathrm{Zn}$ metal, PA, when using NAC, compared to the other extractants tested, ammonium chloride (at concentrations of $1,1.5$ and $2 \mathrm{~mol} \mathrm{~L}^{-1}$ ), and $2 \%$ citric acid solution. The authors recommended NAC diluted $1+9$ as best extractor for $\mathrm{Zn}$ oxide PA, which is the chemical form authorized by law for products containing water-insoluble zinc and for zinc marketed as simple mineral fertilizer. In fact, the $\mathrm{Zn}$ extraction capacity of NAC is high for sources containing $\mathrm{Zn}$ in oxide form, as evidenced in the industrial by-products galvanizing ash and brass ash (Table 3), from which Zn was extracted at levels exceeding $70 \%$ (Table 5). Interestingly, also with regard to the effect of the chemical form of $\mathrm{Zn}$ on its solubilization in different extractant solutions, $\mathrm{Zn}$ in oxide form and as mineral gahnita $\left(\mathrm{ZnAl}_{2} \mathrm{O}_{4}\right)$ was completely solubilized in the extractors $2 \% \mathrm{CA}, 1 \% \mathrm{AA}$ and $10 \% \mathrm{SA}, 10 \% \mathrm{HCl}$, NAC, and DTPA. The Zn solubility in brass slag II, on the other hand, where the element is contained in the form of silicate (Table 3), was high only in the extractant solutions of $2 \% \mathrm{CA}, 10 \% \mathrm{SA}$ and $10 \%$ $\mathrm{HCl}$, indicating that silicate-bound $\mathrm{Zn}$ is less soluble in the studied extractors. Differences in the mineralogical composition of brass slag with effects on the behavior of various extractors were reported by Moura (2010): in brass slag with $25.3 \% \mathrm{Zn}$ (total content) and $14.7 \% \mathrm{SiO}_{2}, \mathrm{Zn}$ was found in oxidized forms $(\mathrm{ZnO})$, associated with $\mathrm{Cu}$ forming alloy $(\mathrm{CuZn})$, as mineral gahnita $\left(\mathrm{ZnAl}_{2} \mathrm{O}_{4}\right)$ and willemite $\left(\mathrm{Zn}_{2} \mathrm{SiO}_{4}\right)$ with no statistical difference between $\mathrm{Zn}$ extraction by $\mathrm{HCl}$, aqua regia, USEPA $3050 \mathrm{~B}$ modified by Moraes (2009), by $2 \%$ CA and NAC and with lowest extraction by water. Another brass slag evaluated with $18 \% \mathrm{Zn}$ (total content) and $44.7 \% \mathrm{SiO}_{2}$ contained $\mathrm{Zn}$ as oxide and silicate, however, Zn extraction decreased in the extractors aqua regia, $\mathrm{HCl}, 2 \% \mathrm{CA}, \mathrm{NAC}$, USEPA $3050 \mathrm{~B}$ adapted by Moraes (2009), and water. The author related the differences in extractor performance to $\mathrm{Zn}$ solubilization in the slags according to the chemical composition of Zn and the crystallinity $\left(\mathrm{SiO}_{2}\right.$ content) of the materials.

The solubility of galvanic sludge was high in the extractant solutions of DTPA, $2 \% \mathrm{CA}, 10 \% \mathrm{HCl}$, and NAC (Tables 5 and 6), and chemically, this Zn source was composed of the forms zinc oxide (zincite) and hydroxide (Table 3).

The commercial granular $\mathrm{Zn}$ fertilizer was highly soluble in DTPA, $10 \% \mathrm{HCl}, 2 \% \mathrm{CA}$ and NAC (Table 5). The percentage of $\mathrm{Zn}$ recovered compared with the extractor $2 \%$ CA ranged from 97 to $113 \%$ (Table 6) and the chemical composition of zinc consisted of oxide and sulfates (Table 3).

As expected, the $\mathrm{Zn}$ solubility of $\mathrm{Zn}$ sulfate was moderate to high in all extracts (Table 5), for being the only water-soluble source. The $\mathrm{Zn}$ recovery percentage in relation to the $2 \% \mathrm{CA}$ extractor ranged from $39 \%$ by extractor Hwa to 113 by $1 \%$ AA, showing that $\mathrm{Zn}$ sulfate is easily solubilized by several extractors (Table 6).

\section{Phase II: Availability of Zn to maize plants}

In the medium-textured Dystrophic Alic Red Yellow Latosol (DARYL), more Zn was accumulated in the maize shoots than in plants grown on a clayey Dystrophic Red Latosol (DCRL) (Table 7). Zinc accumulation in DARYL was lower in the control and the brass slag II treatments, whereas in DCRL, less $\mathrm{Zn}$ was taken up by plants in the treatments control, zinc sulfate, galvanizing ash and brass slag I and II. The highest Zn accumulation in plants in both soils was promoted by galvanic sludge, followed by Zn sulfate, galvanizing ash, commercial granular Zn, brass ash, and brass slag I in DARYL soil and brass ash and commercial granular Zn in DCRL soil (Table 7). 
In DARYL soil, the sources galvanizing ash, brass ash, brass slag I and commercial granular Zn led to similar Zn accumulation in plants, not differing from Zn sulfate, the micronutrient source considered soluble.

In plants grown in DRCL soil, the control treatment and sources galvanizing ash and brass slag I and II did not differ in the $\mathrm{Zn}$ levels found in relation to plants grown with $\mathrm{Zn}$ sulfate, whereas the sources galvanic sludge, brass ash and commercial granular $\mathrm{Zn}$ promoted greater $\mathrm{Zn}$ accumulation in maize than the soluble source (Zn sulfate) (Table 7).

The agronomic efficiency index (AEI) of the sources for $\mathrm{Zn}$ accumulation in the shoots showed higher efficiency of the industrial by-product galvanic sludge than of the water-soluble $\mathrm{Zn}$ sulfate, demonstrating that water-insoluble materials, but with chemical composition of $\mathrm{Zn}$ in the form of hydroxides and oxides (Table 3), are readily solubilized in the rhizosphere and made available to the plants (Table 7). A high agronomic efficiency index was also observed for commercial granular Zn (Table 7), with predominance of $\mathrm{Zn}$ in the form of sulfates and oxides (Table 3 ) and for the industrial by-product brass ash with $\mathrm{Zn}$ in oxide form (Table 3). The agronomic efficiency of galvanizing ash was moderate (Table 7), with Zn predominantly in oxide form (mineral zincite) and $\mathrm{Zn}$ chloride hydroxide monohydrate (mineral simonkolleite), an oxide bonded with the $\mathrm{Al}$ and $\mathrm{Zn}$ forming a metallic alloy (gahnita) (Table 3).

The lowest AEI for $\mathrm{Zn}$ accumulated in maize shoots was found for the sources brass slag I and II (Table 7). It should be emphasized that the agronomic efficiency of industrial by-products obtained from a same industrial process, e.g., brass slag I and II, can differ. In this work, brass slag I had an efficiency of $67 \%$ and brass slag II of $27 \%$ (Table 7), with different chemical compositions, oxide versus silicate (Table 3), respectively, which must have influenced the efficiency of these industrial by-products. These results were similar to those found by Moura (2010), who evaluated the agronomic efficiency of two brass slags and two fertilizers were prepared with pure oxides for analysis in rice plants. The author reported high efficiency (94\%) for $\mathrm{Zn}$ source in the form of oxide and bonded with the $\mathrm{Cu}$ forming a metallic alloy, containing $14.7 \%$ $\mathrm{SiO}_{2}$ and lower efficiency (42\%) for the other slag with $\mathrm{Zn}$ in the form of oxide and silicate, containing $44.7 \% \mathrm{SiO}_{2}$. The author attributed this difference to the chemical composition of $\mathrm{Zn}$ and the crystallinity ( $\mathrm{SiO}_{2}$ concentrations) of the industrial by-product. These results clearly show the importance of the chemical composition of the $\mathrm{Zn}$ source for the agricultural efficiency of the evaluated industrial byproducts. Similarly, a study evaluated the availability and efficiency of $\mathrm{Zn}$ from different sources to rice and maize plants and detected greatest availability of the element as $\mathrm{Zn}$ sulfate, followed by $\mathrm{Zn}$ oxide, a residue whose origin and chemical composition have not been disclosed and finally, metallic $\mathrm{Zn}$ and $\mathrm{Zn}$ in the form of frits. The AEI compared to zinc sulfate was around $90 \%$ for the oxide, $80 \%$ for the residue and $50 \%$ for metal $\mathrm{Zn}$ and frits. These authors reported low plant availability for $\mathrm{Zn}$ in the form of silicates and metallic alloys (Vale \& Alcarde, 2002).

Apart from the chemical composition, the particle size of a fertilizer applied to the soil can affect its phytoavailability and, consequently, the agronomic efficiency. A greenhouse study reported that $\mathrm{ZnO}$ and $\mathrm{ZnSO}_{4}$ induced similar responses in maize plants, when applied as powder mixed with soil. However, the sources granular $\mathrm{ZnSO}_{4}$ and $\mathrm{ZnO}$ were considered inefficient and unsatisfactory, respectively (Allen \& Teman, 1966). The efficiency of finely ground zinc oxide is expected to be similar to zinc sulfate (Mortvedt, 1991). A study evaluating Zn availability in ground and granulated material, with water solubility ranging

Table 7. Zn accumulation in maize shoots and agronomic efficiency index (AEI) of applied Zn sources compared to $\mathrm{Zn}$ sulfate $(\mathbf{1 0 0} \%)$

\begin{tabular}{|c|c|c|c|c|c|c|}
\hline \multirow{2}{*}{ Zn source } & \multicolumn{3}{|c|}{ Zn accumulation in shoots } & \multicolumn{3}{|c|}{ AEI } \\
\hline & DARYL & DCRL & Mean & DARYL & DCRL & Mean trat \\
\hline & 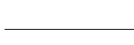 & $\mathrm{mg} / \mathrm{pot}$ & 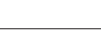 & 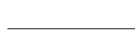 & $\%$ & 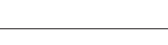 \\
\hline Control & $0.90 \mathrm{c}$ & $0.77 \mathrm{c}$ & $0.83 \mathrm{c}$ & & & \\
\hline Zn sulfate & $1.34 \mathrm{~b}$ & $0.99 \mathrm{c}$ & $1.16 \mathrm{~b}$ & 100 & 100 & 100 \\
\hline Galvanizing ash & $1.25 \mathrm{~b}$ & $0.94 \mathrm{c}$ & $1.10 \mathrm{~b}$ & 80 & 77 & 78 \\
\hline Galvanic sludge & $1.69 \mathrm{a}$ & $1.42 \mathrm{a}$ & $1.56 \mathrm{a}$ & 181 & 295 & 238 \\
\hline Brass ash & $1.34 \mathrm{~b}$ & $1.10 \mathrm{~b}$ & $1.23 \mathrm{~b}$ & 100 & 150 & 125 \\
\hline Brass slag I & $1.21 \mathrm{~b}$ & $0.91 \mathrm{c}$ & $1.06 \mathrm{~b}$ & 70 & 64 & 67 \\
\hline Brass slag II & $1.08 \mathrm{c}$ & $0.80 \mathrm{c}$ & $0.94 \mathrm{c}$ & 41 & 14 & 27 \\
\hline Commerc. Gran. Zn fertilizer & $1.23 \mathrm{~b}$ & $1.23 \mathrm{~b}$ & $1.23 \mathrm{~b}$ & 75 & 209 & 142 \\
\hline Mean & $1.26 \mathrm{~A}$ & $1.02 \mathrm{~B}$ & & & & \\
\hline
\end{tabular}

DARYL: Dystrophic Alic Red Yellow Latosol with medium texture. DCRL: Dystrophic Clayey Red Latosol. Means followed by the same letter in the column do not differ by the Scott-Knott test at $95 \%$ probability for the factor $\mathrm{Zn}$ sources. 
from 0 to $100 \%$, showed that Zn availability was more related to the particle size of the sources, the best results being obtained with powder products. For granular products, it was observed that the higher the water solubility of the fertilizers, the greater the absorption and dry matter of maize plants (Mortvedt, 1992). In this study, based on the mean of the AEI, the high agronomic efficiency of the sources galvanic sludge, commercial granular $\mathrm{Zn}$ and brass ash and the moderate efficiency of galvanizing ash (Table 7) can be partly attributed to the application of these products to the soil in powder form. The same effect of influence of the physical form of the fertilizer on $\mathrm{Zn}$ uptake efficiency was reported in maize plants; the plants responded with considerable dry matter production to all sources evaluated, when applied in powder form. The Zn availability after granular Zn sulfate application was close to zero and lower after granular Zn humate-lignosulfonate application than of the ground form (Goos et al., 2000). The authors concluded that differences in phytoavailability between sources are much more related to the physical than to chemical properties of the products. Another study also highlighted the importance of the physical form, since some products can be partly solubilized in the soil when applied in the form of very fine powder (Vale \& Alcarde, 2002).

In some cases, the efficiency of a particular source can be compensated by increasing the application rate, as mentioned by Malavolta et al. (1987). These authors tested the sources Zn sulfate, oxide and a commercial frit and found that the highest maize yields were obtained by application of $0.5 \mathrm{mg} \mathrm{dm}^{-3} \mathrm{Zn}$ as sulfate or oxide and $1.0 \mathrm{mg} \mathrm{dm}^{-3} \mathrm{Zn}$ as commercial frit. Similarly, the use of industrial by-products in this work, such as brass slag I and II with relatively low AEI (67 and $27 \%$, respectively), could be compensated by increasing the rate, provided the levels of contaminants are not restrictive. The galvanic sludge, another material with interesting chemical composition, although only admitted for Minas Gerais by the local environmental agency and MAPA, is highly promising as $\mathrm{Zn}$ source in fertilizer production, in view of the high agronomic efficiency. In the other States, the use of this industrial by-product is prohibited for not having been regulated by environmental agency.

Doubtlessly, the solubility in the $2^{\text {nd }}$ extractor represented a breakthrough in the quality control of raw material and fertilizers marketed by the production sector. However, based on the assumption that the solubility in the extraction solution reflects the chemical composition of the $\mathrm{Zn}$ source that partly determines the agronomic efficiency of a fertilizer, the chemical composition combined with the AEI of a source is an important factor that should be taken into consideration by MAPA in the evaluation of new micronutrient sources. This aspect is reinforced in this study, since the agronomic efficiency of industrial by-products such as brass ash and galvanizing ash was considerable (78 and $125 \%$, respectively), compared to the standard source $\mathrm{Zn}$ sulfate (Table 7), in spite of not reaching the minimum solubility of 60 in the $2 \%$ CA extractor (Table 4). In summary, if required minimum solubility of $60 \%$ in the $2^{\text {nd }}$ extractor for industrial by-products, other potentially useful materials can be disapproved its use by MAPA. It is noteworthy that the presence of other potentially toxic elements (e.g., $\mathrm{As}, \mathrm{Cd}, \mathrm{Cr}, \mathrm{Pb}$, and $\mathrm{Hg}$ ) could restrict or impair the use of these $\mathrm{Zn}$ sources in agriculture, which was not evaluated in this study.

\section{Evaluation of $2^{\text {nd }}$ extractors}

The correlations to assess the efficiency of extractors in predicting the phytoavailability of different Zn sources were established for each soil type, since the analysis of variance showed different responses to $\mathrm{Zn}$ content and accumulation in maize grown on DARYL (medium texture) and DCRL (clayey) soils.

The correlation between the amount of potentially available $\mathrm{Zn}(\mathrm{mg} / \mathrm{pot})$, according to the solubility of the different $\mathrm{Zn}$ sources in each extractor with $\mathrm{Zn}$ accumulated in the shoot, was significant for NAC and DTPA, regardless of the soil type (Table 8). Furthermore, the correlations between the amount of potentially available $\mathrm{Zn}(\mathrm{mg} /$ pot), according to the solubility of the different $\mathrm{Zn}$ sources in each extractor with the agronomic efficiency index (AEI) of Zn sources (based on Zn accumulated in the shoots) were also significant for the extractors NAC and DTPA in both soils (Table 8). In the DCRL soil (clayey texture), the correlation of the extractor $10 \% \mathrm{HCl}$ was also significant for $\mathrm{Zn}$ shoot accumulation and for the agronomic efficiency of sources (Table 8).

Our study results differ partly from those reported in the literature. The chelating agents DTPA and EDTA, both at $5 \mathrm{mmol} \mathrm{L}^{-1}$, and the extractants water, $2 \% \mathrm{CA}$ and NAC diluted $1+9$ were evaluated by Vale \& Alcarde (1999) for their efficiency in the evaluation of micronutrient availability to rice plants grown in Petri dishes, of 30 samples of commercial fertilizers. Only the extractor $2 \%$ CA proved promising in the characterization of plant-available $\mathrm{Cu}, \mathrm{Mn}$ and $\mathrm{Zn}$. The metal solubility of the chelating agents EDTA and DTPA was generally low. Vale \& Alcarde (2002) also evaluated $\mathrm{Zn}$ in different chemical forms of fertilizers (zinc sulfate, zinc oxide, zinc metal, and four commercial frits) extracted in water, $2 \% \mathrm{CA}$, NAC (1+9) and DTPA $5 \mathrm{mmol} \mathrm{L}^{-1}$. The Zn contents extracted by the different solutions were correlated with the levels of this element in rice and maize plants. The extractor NAC $(1+9)$ at a ratio of 1:100 (fertilizer mass: extraction solution mass) and under boiling for 5 min was considered a good extractor to assess the availability of $\mathrm{Zn}$ fertilizers for rice and maize plants with correlation coefficients significant at $1 \%(0.92$ and 0.96 , respectively). 
Table 8. Coefficients of linear correlation in DARYL (medium texture) and DCRL (clayey) soils between: the amount of potentially available $\mathrm{Zn}$ according to the solubility of $\mathrm{Zn}$ sources in each extractant with $\mathrm{Zn}$ accumulation in maize plants and, the amount of potentially available $\mathrm{Zn}$ according to the source solubility in each extractant with the agronomic efficiency index (AEI) of the sources

\begin{tabular}{|c|c|c|c|c|}
\hline \multirow{2}{*}{ Extractor Zn } & \multicolumn{2}{|c|}{ DARYL } & \multicolumn{2}{|c|}{ DCRL } \\
\hline & Zn accumulation & AEI & Zn accumulation & AEI \\
\hline $\mathrm{mg} /$ pot & $\mathrm{mg} / \mathrm{pot}$ & $\%$ & $\mathrm{mg} /$ pot & $\%$ \\
\hline $\mathrm{HCl}^{(1)}$ & $0.00 \mathrm{~ns}$ & $0.00 \mathrm{~ns}$ & $0.00 \mathrm{~ns}$ & $0.00 \mathrm{~ns}$ \\
\hline $2 \% \mathrm{CA}^{(2)}$ & $0.28 \mathrm{~ns}$ & $0.28 \mathrm{~ns}$ & $0.41 \mathrm{~ns}$ & $0.41 \mathrm{~ns}$ \\
\hline $1 \% \mathrm{AA}^{(3)}$ & $0.65 \mathrm{~ns}$ & $0.65 \mathrm{~ns}$ & $0.50 \mathrm{~ns}$ & $0.50 \mathrm{~ns}$ \\
\hline $10 \% \mathrm{SA}^{(4)}$ & $0.44 \mathrm{~ns}$ & $0.44 \mathrm{~ns}$ & $0.50 \mathrm{~ns}$ & $0.50 \mathrm{~ns}$ \\
\hline $10 \% \mathrm{HCl}^{(5)}$ & $0.58 \mathrm{~ns}$ & $0.58 \mathrm{~ns}$ & $0.75 *$ & $0.75 *$ \\
\hline $\mathrm{NAC}^{(6)}$ & $0.76 *$ & $0.76 *$ & $0.79 *$ & $0.78 *$ \\
\hline DTPA $^{(7)}$ & $0.84 *$ & $0.84 *$ & $0.84 *$ & $0.83 *$ \\
\hline EDTA $^{(8)}$ & $0.03 \mathrm{~ns}$ & $0.03 \mathrm{~ns}$ & $0.00 \mathrm{~ns}$ & $0.00 \mathrm{~ns}$ \\
\hline $\mathrm{BS}$ pH $6.0^{(9)}$ & $0.47 \mathrm{~ns}$ & $0.47 \mathrm{~ns}$ & $0.45 \mathrm{~ns}$ & $0.44 \mathrm{~ns}$ \\
\hline $\mathrm{Wa}^{(10)}$ & $0.09 \mathrm{~ns}$ & $0.09 \mathrm{~ns}$ & $0.17 \mathrm{~ns}$ & $0.18 \mathrm{~ns}$ \\
\hline $\mathrm{HWa}^{(11)}$ & $0.05 \mathrm{~ns}$ & $0.05 \mathrm{~ns}$ & $0.10 \mathrm{~ns}$ & $0.10 \mathrm{~ns}$ \\
\hline
\end{tabular}

${ }^{(1)} \mathrm{HCl}$ : total Zn content, the official MAPA method. ${ }^{(2)} 2 \% \mathrm{CA}: 2 \%$ citric acid. ${ }^{(3)} 1 \%$ AA: $1 \%(\mathrm{v} / \mathrm{v})$ acetic acid. ${ }^{(4)} 10 \%$ SA: $10 \%(\mathrm{v} / \mathrm{v})$ sulfuric acid. ${ }^{(5)} 10 \% \mathrm{HCl}(\mathrm{v} / \mathrm{v}){ }^{(6)} \mathrm{NAC}$ : neutral ammonium citrate + water in the ratio $1: 1{ }^{\left({ }^{(7)}\right.} 50 \mathrm{mmol} \mathrm{L}^{-1} \mathrm{DTPA}^{\left({ }^{(8)}\right.} 5 \mathrm{mmol} \mathrm{L}^{-1} \mathrm{EDTA}$. ${ }^{(9)} \mathrm{BS}$ pH 6.0: buffer solution pH 6.0. ${ }^{(10)}$ Wa: water. ${ }^{(11)}$ HWa: hot water. DARYL: Dystrophic Alic Red Yellow Latosol with medium texture. DCRL: Dystrophic Clayey Red Latosol. AEI: agronomic efficiency index of sources calculated based on Zn accumulation in the shoots. ns and *, not significant and significant at $5 \%$, respectively.

A more recent study by Moura (2010) evaluated the extractors $2 \% \mathrm{CA}$ and NAC (both methods with stirring and boiling), and water to quantify the levels of available $\mathrm{Zn}$ in brass slag for rice plants grown in a clayey soil (Dark Red Latosol). The author reported that the $2 \%$ CA extractor (under boiling) efficiently predicted the $\mathrm{Zn}$ available to rice plants in the industrial by-products, although the linear correlation coefficient ( $\mathrm{r}$ ) between the solubility of $\mathrm{Zn}$ content in the slags and $\mathrm{Zn}$ accumulated in plants was $0.47^{*}$.

The significant correlations obtained by the use of $50 \mathrm{mmol} \mathrm{L}^{-1}$ DTPA can be explained by the change in concentration of the extraction solution, 10 times more concentrated than the DTPA solution tested by other authors (Vale \& Alcarde, 1999, 2002). This modification was based on the fact that the mineral fertilizers contain much higher micronutrient concentrations than the soil. Therefore, the effect of the DTPA concentration was more marked, increasing its chelating ability and capacity of solubilizing $\mathrm{Zn}$ contained in the fertilizer sources evaluated in this study. Of all results obtained, the DTPA $50 \mathrm{mmol} \mathrm{L}^{-1}$ extractor, under stirring, is the most promising as extractant for different $\mathrm{Zn}$ sources.

\section{CONCLUSIONS}

1 . The results of $2^{\text {nd }}$ extractor $2 \%$ citric acid were unsatisfactory for the evaluation of zinc available in industrial by-products and mineral fertilizers and to predict the zinc availability to maize in the tested sources.

2. The extractant $50 \mathrm{mmol} \mathrm{L}^{-1} \mathrm{DTPA}$, with stirring, was the best method that represented Zn availability to maize plants, indicating its potential as Zn extractor from mineral fertilizers and industrial by-products.

3. The agronomic efficiency index of the material that not reaching a minimum solubility of $60 \%$ in the $2^{\text {nd }}$ extractor $2 \% \mathrm{CA}$ was similar to or higher than that of $\mathrm{Zn}$ sulfate. This fact indicates that the adoption of citric acid $2 \%$ to the solubility evaluation for industrial by-products could restrict the use of alternative and potential Zn sources. However, the levels of the contaminants arsenic, cadmium, chromium, lead, and mercury must also be evaluated to ensure a safe use of these sources.

4. It is recommended to use X-ray diffraction analysis in the description of the mineralogical composition of $\mathrm{Zn}$ in several sources, mainly in industrial by-products, which can have a highly variable composition, according to the production process.

\section{ACKNOWLEDGEMENTS}

The authors are indebted to the State of São Paulo Research Foundation for funding the project (FAPESP 2009/01946-0) and the postgraduate scholarship (FAPESP 2010/04076-3). They are grateful to 
researcher Dr. Geraldo Magela da Costa of the Federal University of Ouro Preto, for his help with the X-ray diffraction analysis and to agronomist José Francisco da Cunha of the Tec-Fértil Comércio, Representação e Serviços Ltda for his contribution in the X-ray diffraction analysis interpretation.

\section{LITERATURE CITED}

ABREU, C.A.; LOPES, A.S. \& RAIJ, B.van. Análise de micronutrientes em solos brasileiros: Situação atual e perspectivas. In: CONGRESSO BRASILEIRO DE CIÊNCIA DO SOLO, 26., Rio de Janeiro, 1997. Anais... Rio de Janeiro, 1997. 21p. CD-ROM

ABREU, C.A.; RAIJ, B.van.; ABREU, M.F. \& GONZÁLEZ, A.P. Routine soil testing to monitor heavy metals and boron. Sci. Agríc., 62:564-571, 2005.

ALCARDE, J.C. \& PONCHIO, C.O. A ação solubilizante das soluções de citrato de amônio e de ácido cítrico sobre fertilizantes fosfatados. R. Bras. Ci. Solo, 3:173-178, 1979.

ALCARDE, J.C. \& RODELLA, A.A. Caracterização de fertilizantes simples contendo zinco. Sci. Agríc., 50:121$126,1993$.

ALLEN, E. \& TERMAN, G.L. Response of maize and sudangrass to zinc in granular micronutrients. In: INTERNATIONAL SOCIETY OF SOIL SCIENCE, Aberdeen, 1966. Transactions... Aberdeen, ISSS, 1966. p.255-266.

BASTOS, A.R.R.; CARVALHO, J.G.; FERREIRA, E.V.O.; FARIA JUNIOR, L.A. \& ALCARDE, C.A. Métodos de extração para quantificação de manganês disponível em fertilizantes. Quím. Nova, 30:1616-1622, 2007.

BRASIL. Ministério da Agricultura, Pecuária e Abastecimento. Instrução Normativa SDA № 27, de 05 de junho de 2006. Dispõe sobre fertilizantes, corretivos, inoculantes e biofertilizantes para serem produzidos, importados e comercializados, deverão atender aos limites estabelecidos no que se refere às concentrações máximas admitidas para agentes fitotóxicos, patogênicos ao homem, animais e plantas, metais pesados tóxicos, pragas e ervas daninhas. Diário Oficial da União de 09/ 06/2006. Seção 1. Páginas 15-16.

BRASIL. Ministério da Agricultura, Pecuária e Abastecimento. Instrução Normativa SDA № 05, de 23 de Fevereiro de 2007. Aprova as definições e normas sobre as especificações e as garantias, as tolerâncias, o registro, a embalagem e a rotulagem dos fertilizantes minerais, destinados à agricultura. Diário Oficial da União de 01/03/ 2007a. Página 10.

BRASIL. Ministério da Agricultura, Pecuária e Abastecimento. Instrução Normativa SDA № 28, de 27 de Julho de 2007. Aprovar os Métodos Analíticos Oficiais para Fertilizantes Minerais, Orgânicos, Organo-Minerais e Corretivos, disponíveis na Coordenação-Geral de Apoio Laboratorial - CGAL/SDA/MAPA, na Biblioteca Nacional de Agricultura - BINAGRI e no sítio do Ministério da Agricultura, Pecuária e Abastecimento. Diário Oficial da União de 31/ 07/2007b. Seção 1, página 11.
CAMARGO, O.A.; MONIZ, A.C.; JORGE, J.A. \& VALADARES, J.M.A.S. Métodos de análise química e física de solos do Instituto Agronômico de Campinas. Campinas, Instituto Agronômico de Campinas, 2009. 94p. (Boletim Técnico, 106)

FLORIDA DEPARTMENT OF AGRICULTURE AND CONSUMER SERVICES - FDACS. Division of Agricultural and Environmental Services. Secondary/Micronutrient analysis. Zinc - Soluble FM-833. Available at <http:// www.flaes.org/pdf/FM-833.pdf>. Accessed Nov 17, 2008.

GABOS, M.B. Lixiviação e absorção de chumbo pelo feijão-deporco assistido pela aplicação de EDTA no solo. Campinas, Instituto Agronômico de Campinas, 2008. 52p. (Dissertação de Mestrado)

GALLO, J.R. Estudo da solubilidade, em solução de ácido acético a $1 \%$, de alguns materiais calcários de grau de finura comercial. Bragantia, 13, 1954. (Número Único)

GOMIDE, I. Materiais secundários com potencial de utilização na produção de fertilizantes micronutrientes. In: REUNIÃO ORDINÁRIA DO GRUPO DE TRABALHO INTERINSTITUCIONAL SOBRE USO DE RESÍDUOS INDUSTRIAIS INDICADOS COMO MATÉRIA PRIMA PARA FABRICAÇÃO DE PRODUTOS FORNECEDORES DE MICRONUTRIENTES UTILIZADOS COMO INSUMO AGRÍCOLA, 4., São Paulo, 2009. Available at <http:// www.mma.gov.br/port/conama/reunalt.cfm?cod_ reuniao=1143>. Accessed Jul 21, 2011.

GOOS, R.J.; JOHNSON, B.E. \& THIOLLET, M. A comparison of the availability of three zinc sources to maize (Zea mays L.) under greenhouse conditions. Biol. Fert. Soils, 31:343-347, 2000.

GUPTA, U.C. Micronutrientes e elementos tóxicos em plantas e animais. In: FERREIRA, M.E.; CRUZ, M.C.P.; RAIJ, B.van \& ABREU, C.A., eds. Micronutrientes e elementos tóxicos na agricultura. Jaboticabal, CNPq/FAPESP/ Potafos, 2001. p.13-41.

MALAVOLTA, E.; PAULINO, V.T.; LOURENÇO, A.J.; MALAVOLTA, M.L.; ALCARDE, J.C.; CORRÊA, J.C.; TERRA, M.M. \& CABRAL, C.P. Eficiência relativa de fontes de zinco para o milho (Zea mays L.). Anais ESALQ, 44:57-76, 1987.

MALAVOLTA, E. Informação agronômica sobre nutrientes para as culturas. In: NUTRIFATOS. Piracicaba, 1996. p.124. (Arquivo do Agrônomo, 10)

MORAES, M.F. Micronutrientes e metais pesados tóxicos: do fertilizante ao produto agrícola. Piracicaba, Centro de Energia Nuclear na Agricultura da Universidade de São Paulo, 2009. 108p. (Tese de Doutorado)

MORTVEDT, J.J. Micronutrients fertilizer technology. In: MORTVEDT, J.J.; COX, F.R.; SHUMAN, L.M. \& WELCH, R.M., eds. Micronutrients in agriculture. 2.ed. Madison, Soil Science Society of America, 1991. p.523-548.

MORTVEDT, J.J. Crop response to level of water-soluble zinc in granular zinc fertilizers. Fert. Res., 33:249-255, 1992.

MOURA, T.A. Fontes de zinco e cobre de origem secundária: caracterização, solubilidade e disponibilidade à plantas de arroz. Piracicaba, Escola Superior de Agricultura Luiz de Queiroz, 2010. 103p. (Dissertação de Mestrado) 
NORVELL, W.A. Comparison of chelating agents as extractants for metals in diverse soil materials. Soil Sci. Soc. Am. J., 48:1285-1292, 1984.

RAIJ, B.van; ANDRADE, J.C.; CANTARELLA, H. \& QUAGGIO, J.A. Análise química para avaliação da fertilidade de solos tropicais. Campinas, Instituto Agronômico de Campinas, 2001. 285p.

SOUZA, C.P.C. Disponibilidade de cobre e zinco em fertilizantes minerais e materiais secundários. Campinas, Instituto Agronômico de Campinas, 2012. 163p. (Dissertação de Mestrado)
VALE, F. \& ALCARDE, J.C. Solubilidade e disponibilidade dos micronutrientes em fertilizantes. R. Bras. Ci. Solo, 23:441-451, 1999.

VALE, F. \& ALCARDE, J.C. Extratores para avaliar a disponibilidade do zinco em fertilizantes. R. Bras. Ci. Solo, 26:655-662, 2002.

YAMADA, T. Deficiências de micronutrientes, ocorrências, detecção e correção: o sucesso da experiência brasileira. Inf. Agron., 105:1-12, 2004. (Encarte) 